\title{
Effect of Atmospheric Pressure Plasma Jet on Inactivation of Listeria monocytogenes, Quality, and Genotoxicity of Cooked Egg White and Yolk
}

\author{
Hyun Jung Lee, Hyun Pa Song ${ }^{1}$, Heesoo Jung ${ }^{2}$, Wonho Choe ${ }^{3}$, Jun Sang Ham4, \\ Jun Heon Lee, and Cheorun Jo* \\ Department of Animal Science and Biotechnology, Chungnam National University, Daejeon 305-764, Korea \\ ${ }^{I}$ Department of Radiation Biotechnology, Advanced Radiation Technology Institute, Jeongeup 580-185, Korea \\ ${ }^{2}$ Agency for Defense Development, Daejeon 305-152, Korea \\ ${ }^{3}$ Department of Physics, Korea Advanced Institute of Science and Technology, Daejeon 305-701, Korea \\ ${ }^{4}$ Quality Control and Utilization Division, National Institute of Animal Science, RDA, Suwon 441-706, Korea
}

\begin{abstract}
The objective of this study was to evaluate the effects of an atmospheric pressure plasma (APP) jet on L. monocytogenes inactivation, quality characteristics, and genotoxicological safety of cooked egg white and yolk. APP treatment using He gas resulted in a 5 decimal reduction in the number of L. monocytogenes in cooked egg white, whereas that using $\mathrm{He}+\mathrm{O}_{2}, \mathrm{~N}_{2}$, and $\mathrm{N}_{2}+\mathrm{O}_{2}$ decreased the number further, and to undetectable levels. All treatments of cooked egg yolk resulted in undetectable levels of inoculated L. monocytogenes. There were no viable cells of total aerobic bacteria after APP treatment on day 0 while the control showed approximately 3-4 Log CFU/g. On day 7, the numbers of total aerobic bacteria had increased by approximately $3 \mathrm{log}$ cycles in cooked egg white, but there were no viable cells in cooked egg yolk after 2 min of APP jet. APP treatment decreased the $L^{*}$-values of cooked egg white and yolk significantly on day 0 . No significant sensory differences were found among the cooked egg white samples, whereas significant reductions in flavor, taste, and overall acceptability were found in cooked egg yolks treated with APP jets. SOS chromotest did not reveal the presence of genotoxic products following APP treatments of cooked egg white and yolk. Therefore, it can be concluded that APP jets can be used as a non-thermal means to enhance the safety and extend the shelf-life of cooked egg white and yolk.
\end{abstract}

Key words: atmospheric pressure plasma jet, cooked egg, L. monocytogenes, quality, genotoxicity

\section{Introduction}

Even though product safety is the ultimate goal in the food industry, outbreaks of foodborne diseases become more frequent every year. According to the Korea Food and Drug Administration, foodborne diseases in Korea have increased 1.2 folds from 2009 to 2010 (KFDA, 2011).

To enhance food safety, studies on non-thermal treatments such as irradiation, high hydrostatic pressure, and natural antimicrobials have been encouraged due to their possible use in fresh foods (Devlieghere et al., 2004). These non-thermal treatments are known to be more favorable as they are characterized by minimum changes in sensorial, nutritional, and functional characteristics compared with thermal treatment (Yun et al., 2010). However,

\footnotetext{
*Corresponding author: Cheorun Jo, Department of Animal Science and Biotechnology, Chungnam National University, Daejeon 305-764, Korea. Tel: 82-42-821-5774, Fax: 82-42-825-9754, E-mail: cheorun@cnu.ac.kr
}

they also have some limitations. Irradiation may produce sensorial and nutritional losses, off-flavor, and lipid oxidation after treatment of certain dose levels or higher, and, more importantly, it must overcome the negative impression held by customers. High pressure has limitations in commercial use due to batch size and its adverse effects on lipid oxidation and texture in treated foods (Kruk et al., 2011).

Atmospheric pressure plasma (APP) is considered as an emerging method for enhancing food safety (Lee et al., 2006). APP was developed to be applied for surface modification in engineering and environmental and biomedical fields (Bogaerts et al., 2002). The active species generated include atoms, molecules, radicals, and UV photons, have an inactivation effect through chemical reactions, resulting in the destruction of the genetic materials of microorganisms (Moisan et al., 2001; Moisan et al., 2002). Basaran et al. (2008) applied sulfur hexafluoride $\left(\mathrm{SF}_{6}\right)$ and air APP to the surface of nuts and reported 
effective inactivation of Aspergillues parasiticus using both gases. Furthermore, sensorial acceptance of different nuts did not change upon APP treatment. Niemira et al. (2008) investigated the inactivation effect of APP in apples and found that exposure time and flow rate were factors affecting the inactivation effect of APP as well as the characteristics of the microorganisms. Moon et al. (2009) investigated the effect of APP treatment on pork and human skin. There was no electrical or thermal damage produced by the treatment. Ragni et al. (2010) reported effective pathogen inactivation with no specific quality changes in egg, including surface color, $\mathrm{pH}$, weight loss, and yolk index, when APP was applied to egg shells. Kim et al. (2011) whilst treating bacon and found that the inactivation of pathogens increased as exposure time and input power were increased. Also, $\mathrm{O}_{2}$ addition increased the efficiency of the APP, which is agreed well with Gweon et al. (2009). The authors also reported that no specific quality changes were found in APP-treated bacon, including $\mathrm{pH}$, TBARS value, and surface color.

The previous studies clearly demonstrate potential of using APP for enhancing safety and extending shelf-life of foods. However, there are some limitations, including broad variation in inactivation efficiency stemming from the different surface characteristics of the foods when using large area-type APP (Song et al., 2009a; Yun et al., 2010). For food use, previous studies revealed that APP with a pen-type device possesses high inactivation efficiency against Listeria monocytogenes in a model system and/or on the surface of chicken breast and ham (Lee et al., 2011). However, quality aspect, including sensory quality which is the most important in food use for APP and information on the genotoxicological safety of APPtreated food products remains unknown.

Therefore, the objective of this study was to evaluate the effects of APP jet on the inactivation of L. monocytogenes and quality characteristics of model cooked egg white and yolk product. The genotoxicological safety of APP-treated samples was also screened using SOS chromotest.

\section{Materials and Methods}

\section{Sample preparation}

Eggs were purchased from a local market in Daejeon, Korea. The samples were transferred to a laboratory, broken, and separated into egg white and yolk. Egg white and yolk were poured into petri dishes $(45 \mathrm{~mL}$ each, Difco Laboratories, USA) and steamed in water bath for $30 \mathrm{~min}$ at $90^{\circ} \mathrm{C}$. After cooking and cooling in air, the cooked egg white and yolk samples were taken out and cut into $10 \times 10 \times 1 \mathrm{~mm}$ (length $\times$ width $\times$ height $)$ sections. Prior to inoculation of $L$. monocytogenes, the samples in petri dishes $(50 \times 10 \mathrm{~mm}$, Difco) were sterilized using UV light for $30 \mathrm{~min}$.

\section{Microorganism and inoculation}

L. monocytogenes (KCTC 3596) obtained from the Korean Collection for Type Culture (KCTC, Korea) was cultured at $37^{\circ} \mathrm{C}$ for $18 \mathrm{~h}$ in tryptic soy broth $(50 \mathrm{~mL})$ (Difco Laboratories, USA). The culture was transferred to a $50 \mathrm{~mL}$ centrifuge tube and centrifuged $(2,090 \mathrm{~g}$ for 10 $\min$ at $4^{\circ} \mathrm{C}$ ) in a refrigerated centrifuge (UNION 32R, Hanil Science Industrial Co., Ltd., Korea). The pellet was then washed twice with sterile saline $(0.85 \%)$ and suspended in saline to a final concentration of approximately $10^{8} \mathrm{CFU} / \mathrm{mL}$. The test culture suspension $(10 \mu \mathrm{L})$ was inoculated into 5 points of the prepared cooked egg white and yolk and spread. To facilitate the attachment of microorganisms to the samples, the samples were left for $1 \mathrm{~h}$ at room temperature (approximately $22^{\circ} \mathrm{C}$ ).

\section{Treatment with APP jet}

The device for APP used for the present study was a micro plasma jet (Jung et al., 2011; Lee et al., 2011). The sample was treated with the plasma produced at $2 \mathrm{kV}$ peak-to-peak voltage. The cooked egg white and yolk samples were treated under plasma for $2 \mathrm{~min}$. $\mathrm{He}$ and $\mathrm{N}_{2}$ were used to generate plasma at a fixed flow rate of $7 \mathrm{~L} /$ min. In order to observe the effect of the gas mixture, $\mathrm{O}_{2}$ $(0.07 \mathrm{~L} / \mathrm{min})$ was added to each gas treatment. For plasma treatment, inoculated samples were placed on the bottom conductor in direct contact with the plasma. The distance between the powered electrode and the treatment surface was maintained at $4 \mathrm{~cm}$. After the treatment, the samples were stored under commercial storage conditions $\left(10^{\circ} \mathrm{C}\right)$ and then measured for their microbial population on days 0 and 7.

\section{Microbiological analysis}

After 2 min of APP treatment, cooked egg white and yolk $(0.5 \mathrm{~g})$ were vortexed with $4.5 \mathrm{~mL}$ of sterile saline $(0.85 \%)$ for $5 \mathrm{~min}$ each. The samples for microbial counts were prepared in a series of decimal dilutions utilizing sterile saline. The media used for $L$. monocytogenes and total aerobic bacterial counts were tryptic soy agar (Difco Laboratories). Each diluent (100 $\mu \mathrm{L})$ was spread in triplicate, and the plates were incubated at $37^{\circ} \mathrm{C}$ for $24 \mathrm{~h}$. The 
number of microorganisms was counted and expressed as $\log \mathrm{CFU} / \mathrm{g}$.

\section{Surface color}

The samples were placed on a round-shaped quartz cell ( $8 \mathrm{~mm}$ diameter), after which the CIE color value was measured using a Color Difference Meter (Spectrophotometer CM 3500d, Minolta Co., Ltd., Japan). The instrument was calibrated to standard black and white plate before analysis. A small size aperture (3 $\mathrm{mm}$ diameter) was used, and three measurements at different sites of each sample were averaged and used as one replication.

\section{pH}

The cooked egg white and yolk samples (1 g) were homogenized (1,130 g, T25 Basic, Ika Co., Germany) with $9 \mathrm{~mL}$ of distilled water for $30 \mathrm{sec}$, and $\mathrm{pH}$ was measured using a pH meter (Model 750, iSTEC, Korea) after calibration using standard buffers from the manufacturer at $\mathrm{pH} 4,7$, and 10 at room temperature.

\section{2-Thiobarbituric acid-reactive substances (TBARS) value}

Three grams of each cooked egg white and yolk sample was homogenized (IKA) with $9 \mathrm{~mL}$ of distilled water for $30 \mathrm{sec}(1,130 \mathrm{~g})$. The homogenate $(1 \mathrm{~mL})$ was transferred to a $15 \mathrm{~mL}$ test tube and then mixed with TBA/TCA solution $(2 \mathrm{~mL})$. The tubes were then heated for $30 \mathrm{~min}$ in a water bath $\left(90^{\circ} \mathrm{C}\right)$, cooled, and centrifuged at $2,090 \mathrm{~g}$ (UNION 32R, Hanil Science industrial, Co., Ltd., Korea). The absorbance of the supernatant was measured at 532 nm using a spectrophotometer $\left(\mathrm{DU}^{\circledR} 530\right.$, Beckman Instruments Inc., USA). TBARS value (mg malondialdehyde/kg sample) was calculated using a standard curve.

\section{Volatile basic nitrogen (VBN)}

VBN measurement in cooked egg white and yolk was carried out following the method of Kruk et al. (2011). Three grams from both samples were homogenized (IKA) with $3 \mathrm{~mL}$ of distilled water and $6 \mathrm{~mL}$ of $10 \%$ TCA for $30 \mathrm{sec}(1,130 \mathrm{~g})$, followed by centrifugation at 2,090 $\mathrm{g}$ (Hanil) for $15 \mathrm{~min}$. The supernatant was filtered using a filter paper (Whatman No 4), after which the filtrate was placed in a test tube and then made up to a final volume of $30 \mathrm{~mL}$ with $5 \%$ TCA. A volume of $0.01 \mathrm{~N}$ boric acid as a VBN absorber was placed in the inner section of a Conway micro-diffusion cell (Sibata Ltd., Japan). Then, $1 \mathrm{~mL}$ of sample solution and $1 \mathrm{~mL}$ of saturated $\mathrm{K}_{2} \mathrm{CO}_{3}$ were also placed into the outer section of the same cell, and the lid was immediately closed. TCA solution $(5 \%)$ was used as a blank. The cell was incubated at $37^{\circ} \mathrm{C}$ for $120 \mathrm{~min}$ and then titrated against $0.02 \mathrm{~N}$ sulfuric acid. VBN value was calculated as ammonia equivalent using the following equation:

VBN value $(\mathrm{mg} \%)=[0.28 \times($ titration volume of sampletitration volume of blank) $\times 10] \times 100$

\section{Sensory evaluation}

Ten panelists were used for the sensory evaluation. The panelists had at least 1 year of experience in sensory evaluation, but were not trained specifically for this experiment. The samples, APP-treated cooked egg white and yolk, were cut into $30 \times 30 \times 1 \mathrm{~mm}$ (length $\times$ width $\times$ height) sections before serving to the panelists and then evaluated using a 9-point hedonic scale (1, dislike extremely; 5 , neither dislike nor like; 9, like extremely). The parameters for sensory evaluation tested were color, flavor, taste, texture, and overall acceptance. A white-colored plastic tray with a random three-digit number was used to provide the samples to each panelist, and water was provided to rinse the oral cavity during the sensory session.

\section{SOS chromotest}

SOS chromotest was carried out following the method of Quillardet and Hofnung (1985) and Song et al. (2009b). E. coli PQ37 suspension was diluted to 1:50 (v/v) using L-medium (bacto tryptone, bacto yeast extract, $\mathrm{NaCl}$, and ampicillin), then cultured for $2 \mathrm{~h}\left(5 \times 10^{6} \mathrm{CFU} / \mathrm{mL}\right)$. The solution was prepared in a series of decimal dilutions utilizing L-medium for direct test and S9 mix for indirect test. S9 mix was made using S9 fraction and cofactor (Wako Co., Japan). APP-treated samples and control group $(20 \mu \mathrm{L})$ were added to the prepared solution $(0.6 \mathrm{~mL})$ and then cultured at $37^{\circ} \mathrm{C}$ for $2 \mathrm{~h}$ to induce SOS response. To prevent the influence from the absorbed spectrum, culture solution was centrifuged in a refrigerated centrifuge, the upper layer was discarded, and then L-medium (0.6 mL) was suspended. $\beta$-Galactosidase and phosphatase assays were performed with the suspension $(0.2 \mathrm{~mL})$. $\beta$-Galactosidase assay was performed with $0.2 \mathrm{~mL}$ of suspension and $1.8 \mathrm{~mL}$ of $\mathrm{B}$ buffer $\left(\mathrm{Na}_{2} \mathrm{HPO}_{4}, \mathrm{NaH}_{2} \mathrm{PO}_{4}, \mathrm{H}_{2} \mathrm{O}, \mathrm{KCl}\right.$, $\mathrm{MgSO}_{4}, 7 \mathrm{H}_{2} \mathrm{O}$, sodium dodecyl sulfate, and $\beta$-mercaptoethanol) at $37^{\circ} \mathrm{C}$ for $10 \mathrm{~min}$, after which $0.4 \mathrm{~mL}$ of onitrophenyl- $\beta$-D-galactoopyranoside (ONPG) was added for color reaction. $\mathrm{Na}_{2} \mathrm{CO}_{3}(1 \mathrm{M}, 1.4 \mathrm{~mL})$ was added to stop the response, and then the absorbance of the supernatant was measured at $415 \mathrm{~nm}$ using a spectrophotome- 
ter. For alkaline phosphatase assay, P buffer (SDS, Tris), P-nitrophenyl phosphate disodium (PNP, $4 \mathrm{mg} / \mathrm{mL}$ ), and $3.75 \mathrm{M} \mathrm{HCl}(0.7 \mathrm{~mL})$ were used instead of $\mathrm{B}$ buffer, ONPG, and $1 \mathrm{M} \mathrm{Na}_{2} \mathrm{CO}_{3}$, respectively. Tris solution ( $2 \mathrm{M}$, $0.7 \mathrm{~mL}$ ) was added for color reaction after $10 \mathrm{~min}$, and then the absorbance of the supernatant was measured at $400 \mathrm{~nm}$ using a spectrophotometer.

\section{Statistical analysis}

Three different trials were individually carried out, and two observation numbers were obtained per trial. Statistical analysis was performed by one-way Analysis of Variance (ANOVA), and significant differences between mean values were identified by Student-Newman-Keul's multiple range test using SAS software with a confidence level at $p<0.05$ (SAS, Release 9.2, SAS Institute Inc., USA). Mean values and standard errors of the mean (SEM) are reported.

\section{Results and Discussion}

\section{Inactivation of $L$. monocytogenes}

The inoculated level for $L$. monocytogenes was 6.68 and $7.07 \mathrm{Log}$ CFU/g in cooked egg white and yolk, respectively, at the initial stage. APP treatment for 2 min using He resulted in a $5.68 \log$ reduction in the number of $L$. monocytogenes, whereas that using $\mathrm{He}$ combined with $\mathrm{O}_{2}$ decreased the number further to an undetectable level $\left(<10^{1} \mathrm{CFU} / \mathrm{g}\right)$ in cooked egg white (Fig. 1). APP treatment using $\mathrm{N}_{2}$ and $\mathrm{N}_{2}+\mathrm{O}_{2}$ also showed significant inactivation (approximately 7 decimal reductions) of $L$. monocytogenes. All treatments in cooked egg yolk, regardless of the gas treatment used, resulted in undetectable levels of inoculated L. monocytogenes. Our previous study in inactivation of $L$. monocytogenes reported 1.37-4.73 log reduc- tions in chicken breast and 1.94-6.52 log reductions in ham using a similar APP jet. APP jet for 2 min reduced the number of $L$. monocytogenes by $0.87,4.19,4.26$, and $7.59 \log$ cycles when $\mathrm{He}, \mathrm{He}+\mathrm{O}_{2}, \mathrm{~N}_{2}$, and $\mathrm{N}_{2}+\mathrm{O}_{2}$ were used, respectively, on an agar model system (Lee et al., 2011). This result clearly indicates that APP jet was effective in inactivating $L$. monocytogenes in various food products. When Song et al. (2009a) used a large area-type $\mathrm{APP}$ at 100 and $150 \mathrm{~W}$ of input power, the number of three-strain cocktail L. monocytogenes on cheese decreased approximately 2 and $8 \log$ cycles, respectively, but only 1 log cycle on the surface of ham. Kim et al. (2011) reported only three decimal reduction upon treating bacon with the same type of APP for $1.5 \mathrm{~min}$ at $125 \mathrm{~W}$ of input power. The authors also indicated that $150 \mathrm{~W}$ of input power produced a significant amount of heat during APP production. Thus, the maximum power for treatment is possibly $125 \mathrm{~W}$ when large area-type APP is used.

The initial numbers of total aerobic bacteria were 2.89 and $2.32 \mathrm{Log}$ CFU/g in cooked egg white and yolk, respectively. There were no viable cells counted in any of the samples on day 0 after 2 min of APP jet (Fig. 2). On day 7 , the numbers of total aerobic bacteria had increased by approximately $3 \log$ cycles in cooked egg white but no viable cells in cooked egg yolk after 2 min of APP jet. There were no differences found among the samples treated with APP jet using $\mathrm{He}, \mathrm{He}+\mathrm{O}_{2}$, and $\mathrm{N}_{2}$ gas; however, the gas mixture $\mathrm{N}_{2}+\mathrm{O}_{2}$ showed a significantly lower number of total aerobic bacteria compared to those of the other treatments. Lee et al. (2011) also reported APP jet supplied with $\mathrm{N}_{2}+\mathrm{O}_{2}$ was the most effective in inactivating $L$. monocytogenes on processed meat surfaces.

The results indicate that the inactivation rate was dependent on the nature of the gas, and inactivation was more effective when the gas was combined with $\mathrm{O}_{2}$ due to the
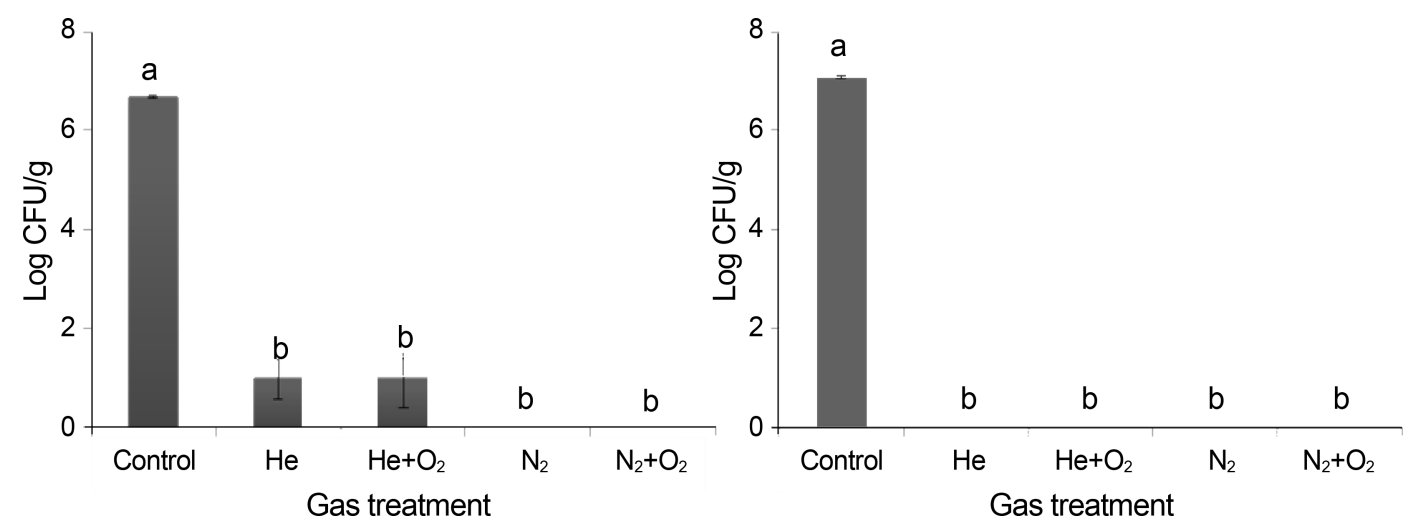

Fig. 1. Effect of atmospheric pressure plasma with different gas compositions on inactivation of Listeria monocytogenes inoculated onto cooked egg white (left) and yolk (right). ${ }^{\text {a,b }}$ Different letters within the same storage day differ significantly $(p<0.05)$. ${ }^{x, y}$ Different letters within the same gas treatment differ significantly $(p<0.05)$. 

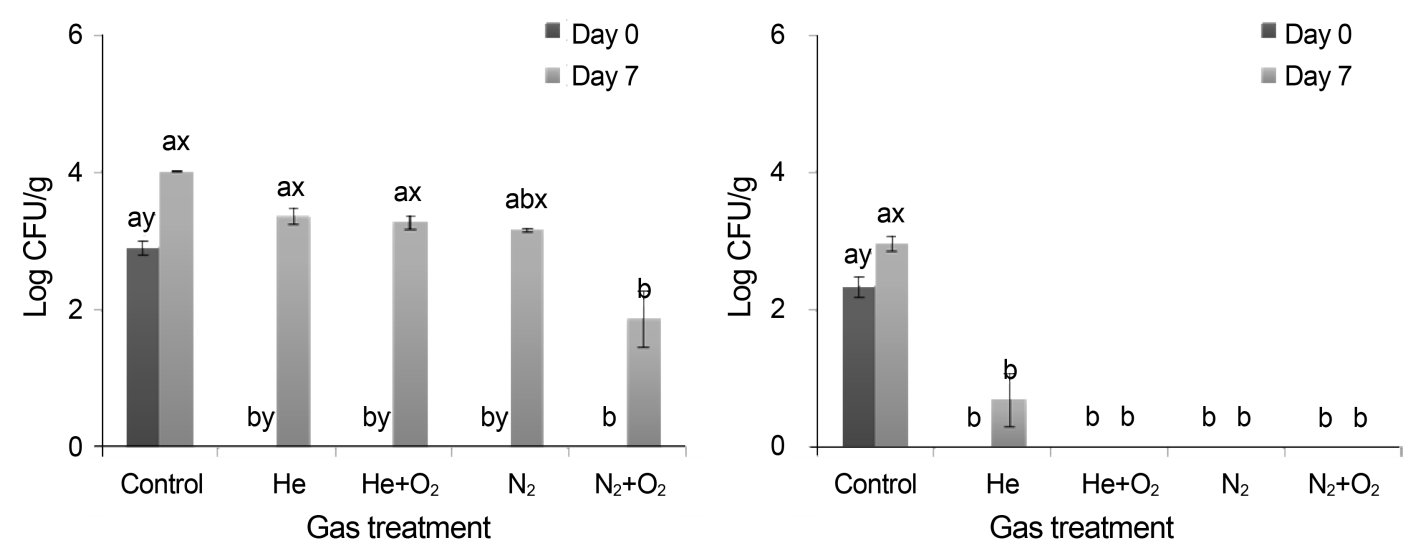

Fig. 2. Effect of atmospheric pressure plasma with different gas compositions on the growth of aerobic bacteria in cooked egg white (left) and yolk (right) during storage for $7 \mathbf{d}$ at $10^{\circ} \mathrm{C} .{ }^{\mathrm{a}, \mathrm{b}}$ Different letters within the same storage day differ significantly $(p<0.05) .{ }^{\mathrm{x}, \mathrm{y}}$ Different letters within the same gas treatment differ significantly $(p<0.05)$.

greater production of radicals based on $\mathrm{O}_{2}$ and ozone by APP treatment (Gweon et al., 2009; Marsili et al., 2002). Yu et al. (2006) and Kim et al. (2011) also previously found that $\mathrm{O}_{2}$ addition resulted in more effective inactivation of inoculated pathogens. Montie et al. (2000) reported that the inactivation rate of different microorganisms is dependent on cell wall structure. Gram-negative cells tend to be more effectively inactivated since their cell wall is thinner compared to Gram-positive cells. In another research, a 7 decimal reduction in apple juice was obtained by treatment with APP, making the authors concluded that the inactivation rate was more effective as input power was increased (Montenegro et al., 2002). However, pathogen inactivation by different APP systems used in previous studies cannot be compared directly due to the different discharge conditions.

\section{Physicochemical properties}

APP treatment decreased the $\mathrm{L}^{*}$-values of cooked egg white and yolk significantly on day 0 (Table 1). Kim et al. (2011) also reported a decrease in $L^{*}$-value with an increase in $\mathrm{a}^{*}$-value of bacon after the treatment of large area-type APP. Moisture content is known to correlate with lightness, such that moisture evaporation from the sample during APP treatment can be a possible explanation for the decrease in $\mathrm{L}^{*}$-value (Kim et al., 2011). However, there were no notable changes in $a^{*}$ - and $b^{*}$-value of cooked egg white and yolk as well by sensory evaluation (Table 3). Other studies also reported no visible changes in color when plasma was treated onto nuts (Basaran et al., 2008), apples (Niemira et al., 2008), pork (Moon et al., 2009), or shell egg (Ragni et al., 2010).

Longer treatment resulted in a lower $\mathrm{pH}$ because $\mathrm{H}^{+}$ concentration dissociated from bacterial molecules and
$\mathrm{H}_{2} \mathrm{O}$ increased during APP treatment (Korachi et al., 2010). Korachi et al. (2010) observed a pH decrease from 7.5 to 1.2 after 20 min of APP treatment in liquid. However, specific $\mathrm{pH}$ changes were not shown in the present study (Table 2). Exposure time may not be long enough to cause $\mathrm{pH}$ decrease. Kim et al. (2011) also did not observe $\mathrm{pH}$ changes between APP-treated and non-treated bacon after 60 or $90 \mathrm{~s}$ of APP.

It is known that the radicals generated using APP either with or without $\mathrm{O}_{2}$, can accelerate the production of peroxides, which are intermediate products of lipid oxidation, so that the TBARS value during storage after APP treatment may increase. Kim et al. (2011) reported that the TBARS value of APP-treated bacon was lower than that of non-treated bacon on day 0 but then increased after $7 \mathrm{~d}$ of storage resulting in higher TBARS value of APP-treated bacon. However, TBARS value was not specifically affected in both APP-treated samples on days 0 and 7 in the present study (Table 2). The changes in TBARS value possibly depends on fat content and fatty acid composition of APP-treated foods (Kim et al., 2011). High pressure treatment, another emerging non-thermal technology, treated to chicken breast fillet at pressures up to $600 \mathrm{MPa}$ increased the TBARS value with pressure on day 0 (Kruk et al., 2011). Gamma or electron beam irradiation also results in accelerated lipid oxidation (Kim et al., 2010). Based on these results, the changes in TBARS value were much smaller in the sample treated with APP compared to other non-thermal processes, indicating APP can be a good candidate of non-thermal technology for food products with high fat content.

VBN content is a method used to measure nitrogen compounds produced during protein catabolism by enzymes from microorganisms (Egan et al., 1981). As the micro- 
Table 1. Effect of atmospheric pressure plasma with different gas compositions on the surface color of cooked egg white and yolk during storage for $7 \mathrm{~d}$ at $10^{\circ} \mathrm{C}$

\begin{tabular}{|c|c|c|c|c|c|c|c|}
\hline \multirow{2}{*}{ Color value } & \multirow{2}{*}{ Input gas ${ }^{1)}$} & \multicolumn{2}{|c|}{ Cooked egg white } & \multirow{2}{*}{ SEM $^{3)}$} & \multicolumn{2}{|c|}{ Cooked egg yolk } & \multirow{2}{*}{$\mathrm{SEM}^{3}$} \\
\hline & & Day 0 & Day 7 & & Day 0 & Day 7 & \\
\hline \multirow{6}{*}{$\mathrm{L}^{*}$} & None & $76.83^{\text {ax }}$ & $75.11^{\text {cy }}$ & 0.178 & $72.82^{\mathrm{ax}}$ & $71.77^{\text {ay }}$ & 0.118 \\
\hline & $\mathrm{He}$ & $76.81^{\text {ax }}$ & $76.06^{\text {by }}$ & 0.110 & $69.26^{\mathrm{b}}$ & $69.13^{\mathrm{b}}$ & 0.469 \\
\hline & $\mathrm{He}+\mathrm{O}_{2}$ & $76.46^{\mathrm{ab}}$ & $75.79^{\mathrm{b}}$ & 0.176 & $60.25^{\mathrm{dx}}$ & $55.10^{\text {cy }}$ & 0.770 \\
\hline & & $76.03^{b x}$ & $75.16^{\text {cy }}$ & 0.073 & $61.52^{\mathrm{dy}}$ & $69.52^{\mathrm{bx}}$ & 0.386 \\
\hline & $\mathrm{N}_{2}+\mathrm{O}_{2}$ & $75.04^{\text {cy }}$ & $77.43^{\mathrm{ax}}$ & 0.299 & $66.37^{\mathrm{cy}}$ & $68.34^{\text {bx }}$ & 0.291 \\
\hline & SEM $^{2)}$ & 0.212 & 0.152 & & 0.525 & 0.386 & \\
\hline \multirow{6}{*}{$a^{*}$} & None & $-4.21^{b}$ & $-4.30^{c}$ & 0.077 & $11.01^{\mathrm{b}}$ & $11.19^{\mathrm{b}}$ & 0.202 \\
\hline & $\mathrm{He}$ & $-3.63^{\mathrm{a}}$ & $-3.83^{\mathrm{a}}$ & 0.055 & $12.46^{\mathrm{ax}}$ & $11.54^{\text {aby }}$ & 0.169 \\
\hline & $\mathrm{He}+\mathrm{O}_{2}$ & $-3.60^{\mathrm{ax}}$ & $-4.05^{\text {aby }}$ & 0.071 & $11.24^{\mathrm{b}}$ & $11.57^{\mathrm{ab}}$ & 0.191 \\
\hline & $\mathrm{N}_{2}$ & $-4.11^{\mathrm{b}}$ & $-4.08^{b}$ & 0.078 & $11.34^{\text {by }}$ & $12.35^{\text {ax }}$ & 0.099 \\
\hline & $\mathrm{N}_{2}^{2}+\mathrm{O}_{2}$ & $-4.15^{\text {by }}$ & $-3.93^{\mathrm{abx}}$ & 0.053 & $10.83^{b}$ & $11.23^{\mathrm{b}}$ & 0.421 \\
\hline & SEM $^{2)}$ & 0.068 & 0.067 & & 0.201 & 0.277 & \\
\hline \multirow{6}{*}{$b^{*}$} & None & $5.66^{\mathrm{ax}}$ & $2.55^{\mathrm{dy}}$ & 0.123 & $47.36^{\text {by }}$ & $51.18^{\mathrm{ax}}$ & 0.412 \\
\hline & $\mathrm{He}$ & $3.77^{\mathrm{b}}$ & $3.65^{\mathrm{b}}$ & 0.150 & $53.06^{\mathrm{ax}}$ & $46.99^{\text {by }}$ & 0.509 \\
\hline & $\mathrm{He}+\mathrm{O}_{2}$ & $3.89^{b x}$ & $3.27^{\text {cy }}$ & 0.056 & $45.52^{\mathrm{b}}$ & $47.38^{b}$ & 1.192 \\
\hline & $\mathrm{N}_{2}$ & $3.92^{\mathrm{b}}$ & $3.47^{\mathrm{bc}}$ & 0.177 & $46.23^{\text {by }}$ & $51.49^{\mathrm{ax}}$ & 0.193 \\
\hline & $\mathrm{N}_{2}+\mathrm{O}_{2}$ & $3.22^{\text {by }}$ & $5.54^{\mathrm{ax}}$ & 0.268 & $46.97^{b}$ & $46.28^{b}$ & 0.361 \\
\hline & SEM $^{2)}$ & 0.210 & 0.116 & & 0.765 & 0.471 & \\
\hline
\end{tabular}

${ }^{1)}$ Gas flow rate, $7 \mathrm{lpm}$ for $\mathrm{He}$ and $\mathrm{N}_{2}$ and $70 \mathrm{sccm}$ for $\mathrm{O}_{2}$

${ }^{2)}$ Standard error of means $(n=6)$

${ }^{3)}(\mathrm{n}=15)$

${ }^{\mathrm{a}-\mathrm{d}}$ Different letters within the same column differ significantly $(p<0.05)$.

${ }^{\mathrm{x}, \mathrm{y}}$ Different letters within the same row differ significantly $(p<0.05)$.

Table 2. Effect of atmospheric pressure plasma with different gas compositions on the quality characteristics of egg white and yolk during storage for $7 \mathrm{~d}$ at $10^{\circ} \mathrm{C}$

\begin{tabular}{|c|c|c|c|c|c|c|c|}
\hline & \multirow{2}{*}{ Input gas ${ }^{1)}$} & \multicolumn{2}{|c|}{ Cooked egg white } & \multirow{2}{*}{ SEM $^{3)}$} & \multicolumn{2}{|c|}{ Cooked egg yolk } & \multirow{2}{*}{$\mathrm{SEM}^{3}$} \\
\hline & & Day 0 & Day 7 & & Day 0 & Day 7 & \\
\hline \multirow{6}{*}{$\mathrm{pH}$} & None & $9.50^{\mathrm{b}}$ & $9.53^{\mathrm{a}}$ & 0.022 & $6.33^{\mathrm{a}}$ & 6.35 & 0.011 \\
\hline & $\mathrm{He}$ & $9.56^{\mathrm{a}}$ & $9.55^{\mathrm{a}}$ & 0.016 & $6.32^{\text {aby }}$ & $6.34^{x}$ & 0.005 \\
\hline & $\mathrm{He}+\mathrm{O}_{2}$ & $9.53^{\mathrm{ab}}$ & $9.51^{\mathrm{ab}}$ & 0.009 & $6.30^{\text {bcy }}$ & $6.35^{\mathrm{x}}$ & 0.009 \\
\hline & $\mathrm{N}_{2}$ & $9.50^{\mathrm{b}}$ & $9.49^{\mathrm{b}}$ & 0.006 & $6.28^{\mathrm{cy}}$ & $6.35^{\mathrm{x}}$ & 0.006 \\
\hline & $\mathrm{N}_{2}+\mathrm{O}_{2}$ & $9.48^{b}$ & $9.44^{\mathrm{c}}$ & 0.009 & $6.28^{\mathrm{cy}}$ & $6.33^{\mathrm{x}}$ & 0.010 \\
\hline & $\mathrm{SEM}^{2)}$ & 0.016 & 0.012 & & 0.008 & 0.010 & \\
\hline \multirow{6}{*}{ TBARS* } & None & $0.16^{\text {ay }}$ & $0.25^{\mathrm{abx}}$ & 0.005 & $2.29^{\mathrm{a}}$ & 2.28 & 0.062 \\
\hline & $\mathrm{He}$ & $0.15^{\text {aby }}$ & $0.25^{\mathrm{abx}}$ & 0.009 & $2.15^{\text {ay }}$ & $2.49^{x}$ & 0.033 \\
\hline & $\mathrm{He}+\mathrm{O}_{2}$ & $0.15^{\text {aby }}$ & $0.25^{\mathrm{abx}}$ & 0.008 & $1.85^{\text {by }}$ & $2.46^{\mathrm{x}}$ & 0.077 \\
\hline & $\mathrm{N}_{2}$ & $0.13^{\text {by }}$ & $0.29^{\mathrm{ax}}$ & 0.014 & $2.25^{\mathrm{a}}$ & 2.45 & 0.102 \\
\hline & $\mathrm{N}_{2}+\mathrm{O}_{2}$ & $0.16^{\text {ay }}$ & $0.24^{\mathrm{bx}}$ & 0.015 & $2.22^{\mathrm{a}}$ & 2.23 & 0.064 \\
\hline & $\mathrm{SEM}^{2)}$ & 0.006 & 0.014 & & 0.056 & 0.083 & \\
\hline \multirow{6}{*}{$\mathrm{VBN}^{* *}$} & None & $9.80^{\text {ey }}$ & $29.87^{\text {ax }}$ & 0.330 & $5.60^{\mathrm{b}}$ & 5.83 & 0.165 \\
\hline & $\mathrm{He}$ & $12.37^{\mathrm{dy}}$ & $31.03^{\mathrm{ax}}$ & 0.617 & $6.07^{\mathrm{ab}}$ & 6.30 & 0.165 \\
\hline & $\mathrm{He}+\mathrm{O}_{2}$ & $17.50^{\text {cy }}$ & $25.67^{b x}$ & 0.165 & $6.07^{\mathrm{ab}}$ & 6.30 & 0.330 \\
\hline & $\mathrm{N}_{2}$ & $28.00^{\mathrm{ax}}$ & $23.80^{\text {cy }}$ & - & $6.30^{\mathrm{a}}$ & 6.30 & - \\
\hline & $\mathrm{N}_{2}+\mathrm{O}_{2}$ & $24.73^{b x}$ & $11.20^{\mathrm{dy}}$ & 0.165 & $5.83^{\mathrm{ab}}$ & 6.30 & 0.165 \\
\hline & SEM $^{2)}$ & 0.148 & 0.443 & & 0.181 & 0.209 & \\
\hline
\end{tabular}

${ }^{1)}$ Gas flow rate: $7 \mathrm{slpm}$ for $\mathrm{He}$ and $\mathrm{N}_{2}$ and $70 \mathrm{sccm}$ for $\mathrm{O}_{2}$

${ }^{2)}$ Standard error of means $(\mathrm{n}=15)$

${ }^{3)}(\mathrm{n}=6)$

${ }^{\mathrm{a}-\mathrm{e}}$ Different letters within the same column differ significantly $(p<0.05)$.

${ }^{x, y}$ Different letters within the same row differ significantly $(p<0.05)$.

*TBARS, 2-thiobarbituric acid reactive substance ( $\mathrm{mg}$ malondialdehyde/ $\mathrm{kg}$ sample)

**VBN, Volatile basic nitrogen (mg/100 g sample) 
bial results showed effective inactivation with APP treatment (Figs. 3 and 4), VBN value in the APP-treated group was expected to be lower than that of the non-treated group. However, VBN value was significantly increased in APP-treated samples, especially following $\mathrm{N}_{2}$ or $\mathrm{N}_{2}+\mathrm{O}_{2}$ treatment (Table 2). After $7 \mathrm{~d}$ of storage, however, VBN contents were significantly lower in the cooked egg white samples treated with $\mathrm{N}_{2}$ and $\mathrm{N}_{2}+\mathrm{O}_{2}$ compared with the results of day 0 . No differences were found in cooked egg yolk. The gases including $\mathrm{N}_{2}$ used for plasma production may be the reason for the higher VBN content on day 0 . Optical emission spectra from the present APP system indicated higher production of $\mathrm{O}_{2}$ and $\mathrm{N}_{2}$-related species, including $\mathrm{N}_{2}{ }^{+}, \mathrm{O}$, and $\mathrm{OH}$, as He flow was increased (Jung et al., 2011). Further, $\mathrm{N}_{2}$ is able to produce more $\mathrm{N}_{2}{ }^{+}$and $\mathrm{N}^{+}$groups compared with $\mathrm{He}$ (Naveed et al., 2006). After 7 days of storage, however, the sample treated with APP jet using $\mathrm{N}_{2}$ or $\mathrm{N}_{2}+\mathrm{O}_{2}$ had the lowest VBN content prob-
Table 3. Effect of atmospheric pressure plasma with different gas compositions for $2 \mathrm{~min}$ on sensory qualities of cooked egg white and yolk

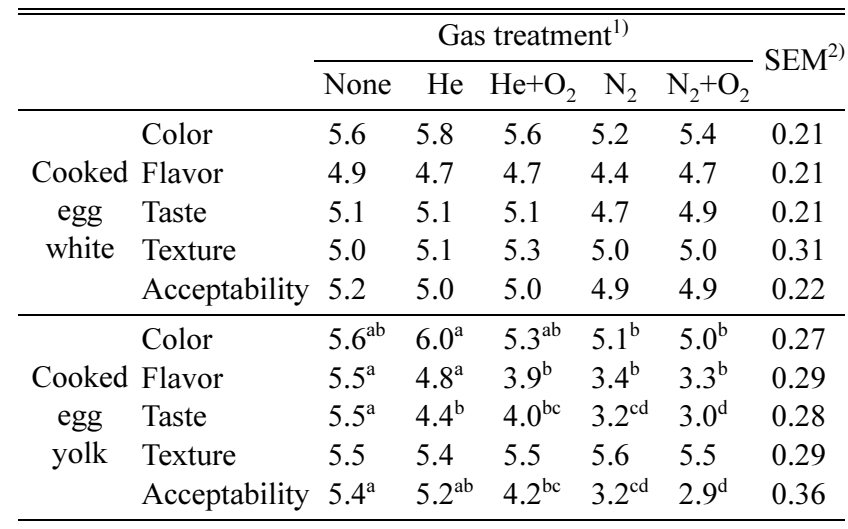

The score was evaluated with 10 semi-trained panelists (1, extremely dislike; 5 , neither dislike nor like; 9 , extremely like).

${ }^{1)}$ Gas flow rate: $7 \mathrm{lpm}$ for $\mathrm{He}$ and $\mathrm{N}_{2}$ and $70 \mathrm{sccm}$ for $\mathrm{O}_{2}$

${ }^{2}$ Standard error of means $(n=50)$.

${ }^{\mathrm{a}-\mathrm{d}}$ Different letters within the same row in different gas treatment differ significantly $(p<0.05)$.

Table 4. SOS chromotest ( $E$. coli PQ37) of egg white treated with atmospheric pressure plasma with different gas compositions

\begin{tabular}{|c|c|c|c|c|c|c|c|c|c|c|c|}
\hline $\begin{array}{c}\text { Gas } \\
\text { treatment }{ }^{1)}\end{array}$ & $\begin{array}{c}\text { Dose } \\
\text { ( } \mu \mathrm{g} / \text { assay })\end{array}$ & $\begin{array}{l}\text { S-9 } \\
\text { mix }\end{array}$ & $\begin{array}{l}\beta \text {-gal } \\
\text { (unit) }\end{array}$ & $\begin{array}{c}\mathrm{ap}^{\mathrm{b}} \\
\text { (unit) }\end{array}$ & Ratio & $\mathrm{IF}^{\mathrm{b}}$ & $\begin{array}{l}\text { S-9 } \\
\text { mix }\end{array}$ & $\begin{array}{l}\beta \text {-gal } \\
\text { (unit) }\end{array}$ & $\begin{array}{c}{ }^{a p^{b}} \\
\text { (unit) }\end{array}$ & Ratio & $\mathrm{IF}^{\mathrm{b}}$ \\
\hline D.W. & & - & 2.00 & 10.10 & 0.20 & 1.00 & + & 3.64 & 15.60 & 0.23 & 1.00 \\
\hline \multirow{5}{*}{ None } & 5000 & - & 2.88 & 12.80 & 0.23 & 1.13 & + & 4.99 & 19.88 & 0.25 & 1.09 \\
\hline & 1250 & - & 2.97 & 12.56 & 0.24 & 1.18 & + & 5.21 & 22.01 & 0.24 & 1.03 \\
\hline & 625 & - & 2.9 & 12.74 & 0.23 & 1.14 & + & 5.07 & 20.99 & 0.24 & 1.05 \\
\hline & 313 & - & 2.66 & 11.15 & 0.24 & 1.19 & + & 4.66 & 19.87 & 0.23 & 1.02 \\
\hline & 156 & - & 2.61 & 12.87 & 0.20 & 1.01 & + & 4.78 & 20.10 & 0.24 & 1.03 \\
\hline \multirow{5}{*}{$\mathrm{He}$} & 5000 & - & 2.98 & 12.90 & 0.23 & 1.16 & + & 4.85 & 20.30 & 0.24 & 1.04 \\
\hline & 1250 & - & 3.02 & 13.45 & 0.22 & 1.12 & + & 5.01 & 19.70 & 0.25 & 1.11 \\
\hline & 625 & - & 3.01 & 13.80 & 0.22 & 1.09 & + & 4.99 & 21.00 & 0.24 & 1.03 \\
\hline & 313 & - & 2.85 & 13.33 & 0.21 & 1.07 & + & 4.78 & 19.60 & 0.24 & 1.06 \\
\hline & 156 & - & 2.90 & 13.10 & 0.22 & 1.11 & + & 4.86 & 20.60 & 0.24 & 1.03 \\
\hline \multirow{5}{*}{$\mathrm{He}+\mathrm{O}_{2}$} & 5000 & - & 3.18 & 13.60 & 0.23 & 1.17 & + & 5.11 & 19.70 & 0.26 & 1.13 \\
\hline & 1250 & - & 3.11 & 13.55 & 0.23 & 1.15 & + & 5.23 & 20.60 & 0.25 & 1.10 \\
\hline & 625 & - & 2.85 & 13.04 & 0.22 & 1.09 & + & 4.76 & 19.80 & 0.24 & 1.05 \\
\hline & 313 & - & 3.01 & 13.65 & 0.22 & 1.10 & + & 4.82 & 19.66 & 0.25 & 1.07 \\
\hline & 156 & - & 3.10 & 13.11 & 0.24 & 1.18 & + & 5.01 & 20.46 & 0.24 & 1.06 \\
\hline \multirow{5}{*}{$\mathrm{N}_{2}$} & 5000 & - & 3.07 & 13.96 & 0.22 & 1.10 & + & 5.28 & 20.66 & 0.26 & 1.11 \\
\hline & 1250 & - & 2.98 & 12.33 & 0.23 & 1.13 & + & 5.40 & 20.05 & 0.27 & 1.17 \\
\hline & 625 & - & 2.56 & 11.97 & 0.21 & 1.07 & + & 4.98 & 19.88 & 0.25 & 1.09 \\
\hline & 313 & - & 2.56 & 11.83 & 0.22 & 1.08 & + & 4.90 & 19.65 & 0.25 & 1.08 \\
\hline & 156 & - & 2.62 & 12.19 & 0.21 & 1.07 & + & 4.55 & 18.01 & 0.25 & 1.10 \\
\hline \multirow{5}{*}{$\mathrm{N}_{2}+\mathrm{O}_{2}$} & 5000 & - & 3.01 & 12.89 & 0.23 & 1.17 & + & 5.11 & 21.10 & 0.24 & 1.05 \\
\hline & 1250 & - & 3.12 & 14.40 & 0.22 & 1.08 & + & 4.91 & 19.55 & 0.25 & 1.09 \\
\hline & 625 & - & 2.98 & 13.12 & 0.23 & 1.14 & + & 4.91 & 19.21 & 0.26 & 1.11 \\
\hline & 313 & - & 3.01 & 13.87 & 0.22 & 1.09 & + & 4.49 & 17.86 & 0.25 & 1.09 \\
\hline & 156 & - & 2.66 & 12.65 & 0.21 & 1.05 & + & 4.5 & 18.8 & 0.24 & 1.04 \\
\hline $4-\mathrm{NQO}^{\mathrm{b}}$ & 0.03 & - & 16.25 & 12.55 & 1.29 & $6.45^{\mathrm{a}}$ & & & & & \\
\hline $\mathrm{B}(\alpha) \mathrm{P}^{\mathrm{b}}$ & 2.5 & + & 13.66 & 16.54 & 0.83 & $4.13^{\mathrm{a}}$ & & & & & \\
\hline
\end{tabular}

${ }^{1)}$ Gas flow rate: $7 \mathrm{lpm}$ for $\mathrm{He}$ and $\mathrm{N}_{2}$ and $70 \mathrm{sccm}$ for $\mathrm{O}_{2}$

${ }^{a}$ Significantly different from the control at $p<0.05$.

${ }^{\mathrm{b}}$ Abbreviations: $\beta$-gal, $\beta$-galactosidase; ap, alkaline phosphatase; IF, induction factor; 4-NQO, 4-nitroquinoline-N-oxide; $\mathrm{B}(\alpha) \mathrm{P}$, benzo $(\alpha)$ pyrene 
ably due to the inactivation of microorganisms in samples by APP treatment.

Table 3 shows the sensory evaluation of cooked egg white and yolk treated with APP jet for 2 min with different gas compositions. No significant sensory differences were found among the cooked egg white samples whereas significant reductions in flavor, taste, and overall acceptability were found in cooked egg yolk treated with APP jet. APP produced by $\mathrm{N}_{2}$ resulted in lower sensory scores for color, flavor, taste, and acceptability compared to those of $\mathrm{He} . \mathrm{O}_{2}$ added to both gas compositions resulted in lower scores for taste and acceptability of cooked egg yolk. Recent study on APP-treated cheese reported that APP using $\mathrm{He}$ and $\mathrm{He}+\mathrm{O}_{2}$ led to significant reductions in flavor, odor, and acceptability after 1, 5, and $10 \mathrm{~min}$ of APP and when $\mathrm{He}$ was combined with $\mathrm{O}_{2}$, the result showed the lowest sensory scores (data not shown). Therefore, sensorial deterioration of APP-treated foods is possibly associated with food type. In contrast to our results, Basaran et al. (2008) demonstrated that sensory evaluations of APP-treated peanut, hazelnut, and pistachio were in the range of "liked moderately" to "liked very much", although there was no significant difference compared with the nontreated group. However, to be developed as a good nonthermal food sterilization method, the sensory deterioration of APP-treated foods should be considered and prevented.

SOS chromotest was carried out to screen the genotoxicological safety of APP-treated samples (Tables 4 and 5). This test is a quantitative bacterial colorimeteric assay for genotoxins (Quillardet et al., 1985). Generally, the genotoxicity test composed of 3 different tests including bacterial reverse mutation test, in vitro chromosome aberration assay, and in vivo micronucleus assay. Ames test is usually used method as bacterial reverse mutation test for screening. SOS chromotest compensates for the short-

Table 5. SOS chromotest (E. coli PQ37) of egg yolk treated with atmospheric pressure plasma with different gas compositions

\begin{tabular}{|c|c|c|c|c|c|c|c|c|c|c|c|}
\hline $\begin{array}{c}\text { Gas } \\
\text { treatment }{ }^{1)}\end{array}$ & $\begin{array}{c}\text { Dose } \\
\text { ( } \mu \mathrm{g} / \mathrm{assay})\end{array}$ & $\begin{array}{l}\text { S-9 } \\
\text { mix }\end{array}$ & $\begin{array}{l}\beta \text {-gal } \\
\text { (unit) }\end{array}$ & $\begin{array}{l}\mathrm{ap}^{\mathrm{b}} \\
\text { (unit) }\end{array}$ & Ratio & $\mathrm{IF}^{\mathrm{b}}$ & $\begin{array}{l}\text { S-9 } \\
\text { mix }\end{array}$ & $\begin{array}{l}\beta \text {-gal } \\
\text { (unit) }\end{array}$ & $\begin{array}{l}\mathrm{ap}^{\mathrm{b}} \\
\text { (unit) }\end{array}$ & Ratio & $\mathrm{IF}^{\mathrm{b}}$ \\
\hline D.W. & & - & 2.39 & 7.20 & 0.33 & 1.00 & + & 3.01 & 15.09 & 0.20 & 1.00 \\
\hline \multirow{5}{*}{ None } & 5000 & - & 2.88 & 8.20 & 0.35 & 1.06 & + & 3.88 & 18.70 & 0.21 & 1.04 \\
\hline & 1250 & - & 2.87 & 8.54 & 0.34 & 1.02 & + & 3.76 & 17.60 & 0.21 & 1.07 \\
\hline & 625 & - & 2.79 & 8.44 & 0.33 & 1.00 & + & 3.79 & 16.88 & 0.22 & 1.08 \\
\hline & 313 & - & 2.39 & 7.23 & 0.33 & 1.00 & + & 3.66 & 15.76 & 0.22 & 1.08 \\
\hline & 156 & - & 2.46 & 7.21 & 0.34 & 1.03 & + & 3.43 & 15.99 & 0.22 & 1.09 \\
\hline \multirow{5}{*}{$\mathrm{He}$} & 5000 & - & 2.86 & 7.66 & 0.37 & 1.13 & + & 3.94 & 17.66 & 0.22 & 1.12 \\
\hline & 1250 & - & 2.76 & 7.87 & 0.35 & 1.06 & + & 3.84 & 17.21 & 0.22 & 1.12 \\
\hline & 625 & - & 2.99 & 8.02 & 0.37 & 1.13 & + & 3.77 & 16.88 & 0.22 & 1.12 \\
\hline & 313 & - & 2.64 & 7.84 & 0.34 & 1.02 & + & 3.65 & 17.50 & 0.21 & 1.04 \\
\hline & 156 & - & 2.51 & 7.50 & 0.33 & 1.01 & + & 3.43 & 17.10 & 0.20 & 1.00 \\
\hline \multirow{5}{*}{$\mathrm{He}+\mathrm{O}_{2}$} & 5000 & - & 2.98 & 7.60 & 0.39 & 1.19 & + & 3.82 & 16.99 & 0.22 & 1.12 \\
\hline & 1250 & - & 3.01 & 7.73 & 0.39 & 1.18 & + & 3.66 & 16.22 & 0.23 & 1.13 \\
\hline & 625 & - & 2.76 & 7.90 & 0.35 & 1.06 & + & 3.75 & 17.01 & 0.22 & 1.10 \\
\hline & 313 & - & 2.77 & 7.30 & 0.38 & 1.15 & + & 3.50 & 16.85 & 0.21 & 1.04 \\
\hline & 156 & - & 2.90 & 8.00 & 0.36 & 1.10 & + & 3.62 & 16.43 & 0.22 & 1.10 \\
\hline \multirow{5}{*}{$\mathrm{N}_{2}$} & 5000 & - & 2.90 & 8.26 & 0.35 & 1.06 & + & 3.71 & 17.13 & 0.22 & 1.08 \\
\hline & 1250 & - & 2.65 & 7.65 & 0.35 & 1.05 & + & 3.64 & 16.44 & 0.22 & 1.11 \\
\hline & 625 & - & 2.70 & 7.9 & 0.34 & 1.04 & + & 3.65 & 16.01 & 0.23 & 1.14 \\
\hline & 313 & - & 2.57 & 7.66 & 0.34 & 1.02 & + & 3.43 & 16.91 & 0.20 & 1.01 \\
\hline & 156 & - & 2.59 & 7.56 & 0.34 & 1.04 & + & 3.68 & 16.80 & 0.22 & 1.10 \\
\hline \multirow{5}{*}{$\mathrm{N}_{2}+\mathrm{O}_{2}$} & 5000 & - & 3.22 & 7.95 & 0.41 & 1.23 & + & 4.22 & 17.62 & 0.24 & 1.20 \\
\hline & 1250 & - & 3.01 & 7.88 & 0.38 & 1.16 & + & 3.98 & 17.73 & 0.22 & 1.12 \\
\hline & 625 & - & 2.88 & 8.44 & 0.34 & 1.03 & + & 3.75 & 16.89 & 0.22 & 1.11 \\
\hline & 313 & - & 3.11 & 8.32 & 0.37 & 1.13 & + & 3.53 & 16.01 & 0.22 & 1.10 \\
\hline & 156 & - & 2.98 & 7.98 & 0.37 & 1.13 & + & 3.45 & 16.8 & 0.21 & 1.03 \\
\hline $4-\mathrm{NQO}^{\mathrm{b}}$ & 0.03 & - & 16.25 & 12.55 & 1.29 & $6.45^{\mathrm{a}}$ & & & & & \\
\hline $\mathrm{B}(\alpha) \mathrm{P}^{\mathrm{b}}$ & 2.5 & + & 13.66 & 16.54 & 0.83 & $4.13^{\mathrm{a}}$ & & & & & \\
\hline
\end{tabular}

${ }^{1}$ Gas flow rate: $7 \mathrm{lpm}$ for $\mathrm{He}$ and $\mathrm{N}_{2}$ and $70 \mathrm{sccm}$ for $\mathrm{O}_{2}$

${ }^{\text {a }}$ Significantly different from the control at $p<0.05$.

${ }^{\mathrm{b}}$ Abbreviations: $\beta$-gal, $\beta$-galactosidase; ap, alkaline phosphatase; IF, induction factor; 4-NQO, 4-nitroquinoline-N-oxide; $\mathrm{B}(\alpha) \mathrm{P}$, benzo $(\alpha)$ pyrene. 
comings of the Ames test, which include personal deviation on counting colonies and amino acids, especially in high protein foods such as egg. It also maintains high correlation $(>90 \%)$ with the results from the Ames test (Quillardet et al., 1985). Results from this study showed that APP-treatment of cooked egg yolk and white did not induce any mutation response. Thus, 2 min treatment with APP jet in the present system may be considered as not leading to genotoxicity. There was no prvious report on genotoxicity test of APP-treated foods so far. Song et al. (2009b) reported that gamma irradiated egg yolk and white had no gentoxicity by SOS chromotest. However, further studies including mouse lymphoma test and chromosome aberration test should be conducted to confirm the genotoxicological safety of APP-treated the cooked egg product.

From the results, it can be concluded that there is potential for using APP jet as a non-thermal sterilization process to enhance safety and extend shelf-life of egg products. However, more appropriate APP system should be developed in minimizing quality changes and maximizing efficiency for food application.

\section{Acknowledgement}

This work was carried out with the support of "Cooperative Research Program for Agriculture Science \& Technology Development (Project No. PJ00733504)" Rural Development Administration, Republic of Korea.

\section{References}

1. Basaran, P., Basaran-Akgul, N., and Oksuz, L. (2008) Elimination of Aspergillus parasiticus from nut surface with low pressure cold plasma treatment. Food Microbiol. 25, 626632.

2. Bogaerts, A., Neyts, E., Gijbels, R., and Mullen, J. (2002) Gas discharge plasmas and their applications. Spectrochim. Acta Part B. 57, 609-658.

3. Deng, S., Ruan, R., Mok, K. C., Huang, G., Lin, X., and Chen, P. (2007) Inactivation of Escherichia coli on almonds using nonthermal plasma. J. Food Sci. 72, M62-M66.

4. Devlieghere, F., Vermeiren, L., and Debevere, J. (2004) New preservation technologies: Possibilities and limitations. Int. Dairy J. 14, 273-285.

5. Egan, H., Kirk, R. S., and Sawyer, R. (1981) Pearson's chemical analysis of foods. UK: Essex: Longman scientific and technical.

6. European Food Safety Authority. (2011) http://www.efsa. europa.eu/en/topics/topic/foodbornediseases.htm. Last access date was May, $16^{\text {th }}, 2011$.
7. Gweon, B., Kim, D. B., Moon, S. Y., and Choe, W. (2009) Escherichia coli deactivation study controlling the atmospheric pressure plasma discharge conditions. Curr. Appl. Phys. 9, 625-628.

8. Jung H., Gweon, B., Kim, D. B., and Choe, W. (2011) A simple approach to surface modification using polytertrafluoroehylene (PTFE) with laminar and turbulent flows of micro plasma jet at atmospheric pressure. Plasma Process Polym. 8, 533-541.

9. Kim, B., Yun, H., Jung, S., Jung, Y., Jung, H., Choe, W., and Jo C. (2011) Effect of atmospheric pressure plasma on inactivation of pathogens inoculated onto bacon using two different gas compositions. Food Microbiol. 28, 9-13.

10. Kim, H. J., Ham, J. S., Kim, K., Ha, J. H., Ha, S. D., and Jo, C. (2010) Quality evaluation of sliced and pizza cheeses treated by gamma and electron beam irradiation. Asian-Aust. J. Anim. Sci. 23, 1112-1117.

11. Korachi, M., Gurol, C., and Aslan, N. (2010) Atmospheric plasma discharge sterilization effects on whole cell fatty acid profiles of Escherchia coli and Staphylococcus aureus. J. Electrostat. 68, 508-512.

12. Korean Food and Drug Administration. (2011) http://www. kfda.go.kr/fm/index.do?nMenuCode $=67$. Last access date was March, $3^{\text {rd }}, 2011$.

13. Kruk, Z. A., Yun, H., Rutley, D. L., Lee, E. J., Kim, Y. J., and Jo, C. (2011) The effect of high pressure on microbial population, meat quality and sensory characteristics of chicken breast fillet. Food Control 22, 6-12.

14. Lee, H. J., Jung, H., Choe, W., Ham, J. S., Lee, J. H., and Jo, C. (2011) Inactivation of Listeria monocytogenes on agar and processed meat surfaces by atmospheric pressure plasma jets. Food Microbiol. 28, 1468-1471.

15. Lee, K., Paek, K. H., Ju, W. T., and Lee, Y. (2006) Sterilization of bacteria, yeast, and bacterial endospores by atmospheric-pressure cold plasma using helium and oxygen. $J$. Microbiol. 44, 269-275.

16. Marzin, D.. R., Olivier, P., and Vophi, H. (1986) Kinetic determination of enzymatic activity and modification of the metabolic activation system in the SOS Chromotest. Mutat. Res. 164, 356-359.

17. Mersch,V., Mersch-Sundermann, V., Kevekordes, S., and Mochayedi, S. (1991) Sources of variability of the Escherichia coli PQ37 genotoxicity assay, Mutat. Res. 252, 51-60.

18. Marsili, L., Espie, S., Anderson, J. G., and Macgregor, S. J. (2002) Plasma inactivation of food-related microorganisms in liquids. Radiat. Phy. Chem. 65, 507-513.

19. Moisan, M., Barbeau, B., Moreau, S., Pelletier, J., Tabrizian, M., and Yahia, L. H. (2001) Low temperature sterilization using gas plasmas: a review of the experiments and an analysis of the inactivation mechanisms. Int. J. Pharm. 226, 121.

20. Moisan, M., Barbeau J., Crevier, M. ED-C., Pelletier, J., Philip, N., and Saoudi, B. (2002) Plasma sterilization: methods and mechanisms. Pure Appl. Chem. 74, 349-358.

21. Montengro, J., Ruan, R., Ma, H., and Chen, P. (2002) Inactivation of $\mathrm{E}$. coli $\mathrm{O} 157: \mathrm{H} 7$ using a pulsed nonthermal plasma 
system. J. Food Sci. 67, 646-648.

22. Moon, S. Y., Kim, D. B., Gweon, B., Choe, W., Song, H. P., and Jo, C. (2009) Feasibility study of the sterilization of pork and human skin surfaces by atmospheric pressure plasmas. Thin Solid Films 517, 4272-4275.

23. Montie, T. C., Kelly-wintenberg, K. and Roth, and J. R. (2000) An overview of research using the one atmosphere uniform glow discharge plasma (OAUGDP) for sterilization of surfaces and marterials. IEEE Trans. Plasma Sci. 28,4150 .

24. Naveed, M. A., Qayyum, A., Ali, S., and Zakaullah, M. (2006) Effects of helium gas mixing on the production of active species in nitrogen plasma. Phys. Lett. A. 359, 499503.

25. Niemira, B.A., and Sites, J. (2008) Cold plasma inactivates Salmonella Stanley and Escherichia coli O157:H7 inoculated on golden delicious apples. J. Food Prot. 71, 13571365.

26. Quillardet, P., and Hofnung, M. (1985) The SOS Chromotest, a colorimetric bacterial assay for genotoxins procedures. Mutat. Res. 147, 65-78.

27. Ragni, L., Berardinelli, A., Vannini, L., Montanari, C., Sirri, F., Guerzoni, M. E., and Guarnieri, A. (2010) Non-thermal atmospheric gas plasma device for surface decontamination of shell eggs. J. Food Eng. 100, 125-132.

28. Song, H. P., Kim, B., Choe, J. H., Jung, S., Moon, S. Y., Choe, W., and Jo, C. (2009a) Evaluation of atmospheric pressure plasma to improve the safety of sliced cheese and ham inoculated by 3 -strain cocktail Listeria monocytogenes. Food Microbiol. 26, 432-436.

29. Song, H. P., Shin, E. H., Yun, H. J., Jo, C., and Kim, D. H. (2009b) Establishing the genotoxicological safety of gammairradiated egg white and yolk. Korean J. Food Preserv. 16, 782-788.

30. World Health Organization. (2007) Food safety and foodborne illness. http://www.who.int/mediacentre/factsheets/ fs237/en/index.html. Last access date was Feb, $20^{\text {th }}, 2011$.

31. Yu, S. Q., Huang, C., Hsieh H.F., Huff, F., and Duan, Y. (2006) Sterilization effects of atmospheric cold plasma brush. Appl. Phys. Lett. 88, 1-3.

32. Yun, H., Kim, B., Jung, S., Kruk, Z. A., Kim, D. B., Choe, W., and Jo, C. (2010) Inactivation of Listeria monocytogenes inoculated on disposable plastic tray, aluminum foil, and paper cup by atmospheric pressure plasma. Food Control 21, 1182-1186.

(Received 2012.3.30/Revised 2012.8.1/Accepted 2012.9.4) 